\title{
Formal and Informal Knowledge and Technology Transfer from Academia to Industry \\ Complementarity Effects and Innovation Performance
}

Grimpe, Christoph; Hussinger, Katrin

\author{
Document Version \\ Accepted author manuscript \\ Published in: \\ Industry and Innovation \\ DOI: \\ $10.1080 / 13662716.2013 .856620$ \\ Publication date: \\ 2013 \\ License \\ Unspecified
}

Citation for published version (APA):

Grimpe, C., \& Hussinger, K. (2013). Formal and Informal Knowledge and Technology Transfer from Academia to Industry: Complementarity Effects and Innovation Performance. Industry and Innovation, 20(8), 683-700. https://doi.org/10.1080/13662716.2013.856620

Link to publication in CBS Research Portal

\section{General rights}

Copyright and moral rights for the publications made accessible in the public portal are retained by the authors and/or other copyright owners and it is a condition of accessing publications that users recognise and abide by the legal requirements associated with these rights.

\section{Take down policy}

If you believe that this document breaches copyright please contact us (research.lib@cbs.dk) providing details, and we will remove access to the work immediately and investigate your claim. 


\section{Formal and Informal Knowledge and Technology Transfer from Academia to Industry: Complementarity Effects and Innovation Performance} Christoph Grimpe and Katrin Hussinger

Journal article (Post print version)

This is an Accepted Manuscript of an article published by Taylor \& Francis in Industry and Innovation on 02 Dec २०13, available online:

http://www.tandfonline.com/10.1080/13662716.2013.856620.

Uploaded to Research@CBS: March 2016 


\title{
Formal and Informal Knowledge and Technology Transfer from Academia to Industry: Complementarity Effects and Innovation Performance
}

\author{
Christoph Grimpe ${ }^{\mathrm{a}, \mathrm{d}}$ and Katrin Hussinger ${ }^{\text {b,c,d }}$ \\ ${ }^{a}$ Copenhagen Business School (Denmark) \\ ${ }^{b}$ University of Luxembourg (Luxembourg) \\ ${ }^{c}$ Katholieke Universiteit Leuven, (Belgium) \\ ${ }^{d}$ ZEW Centre for European Economic Research, Mannheim (Germany)
}

Published in Industry and Innovation, Vol. 20(8), 683-700. The final version can be found at http://www.tandfonline.com/doi/full/10.1080/13662716.2013.856620

\begin{abstract}
Literature has identified formal and informal channels in university knowledge and technology transfer (KTT). While formal KTT typically involves a legal contract on a patent or on collaborative research activities, informal transfer channels refer to personal contacts and hence to the tacit dimension of knowledge transfer. Research is, however, scarce regarding the interaction of formal and informal transfer mechanisms. In this paper, we analyze whether these activities are mutually reinforcing, i.e. complementary. Our analysis is based on a comprehensive dataset of more than 2,000 German manufacturing firms and confirms a complementary relationship between formal and informal KTT modes: using both transfer channels contributes to higher innovation performance. The management of the firm should therefore strive to maintain close informal relationships with universities to realize the full potential of formal KTT.
\end{abstract}

Keywords: University knowledge and technology transfer, complementarity, innovation performance

JEL: L24, O31 


\section{Introduction}

In modern economies, technological progress and growth have frequently been characterized to rely on knowledge produced in the public sector (Jaffe, 1989; Adams, 1990). Private firms have been shown to benefit from close links to academic research because they increase their ability to develop new product and process innovations (Cockburn and Henderson, 1998; Cassiman et al., 2007). The links through which academic science reaches the private sector, however, differ considerably. Prominent and well researched channels are licensing contracts (Jensen and Thursby, 2001; Thursby and Kemp, 2002), joint research projects (Cockburn and Henderson, 1998) or academic consulting (Thursby et al., 2009). In fact, most of the existing research has focused on formal university knowledge and technology transfer (KTT) mechanisms, i.e. those that embody or directly lead to a legal instrument like a patent, license or royalty agreement (Bozeman, 2000; Feldman et al., 2002; Thursby and Thursby, 2002; Siegel and Phan, 2005; Czarnitzki et al., 2012). Only a few authors have investigated informal university KTT mechanisms (e.g. Link et al., 2007; Grimpe and Fier, 2010). Informal KTT focuses on primarily non-contractual interactions of the agents involved, i.e. on university scientists and industry personnel. ${ }^{1}$

While the individual channels of industry collaboration and their contribution to firm innovation performance have received considerable attention in the literature, surprisingly little is known about their interaction. Existing research suggests that formal and informal KTT may go well together (Siegel et al., 2003; Link et al., 2007) in that informal contacts improve the quality of a formal relationship or that formal contracts are accompanied by an informal relation of mutual exchange on technology-related aspects. It is therefore likely that both types may occur simultaneously in order to transfer codified knowledge in the form of a patent or license as well as tacit knowledge through the interaction between the university scientist and industry personnel (Perkmann and Walsh, 2007). It is however unclear whether the joint occurrence of formal and informal KTT benefits innovation performance over and above the contribution of the two modes individually. In other words, in this paper we are interested in whether the two modes are in fact complementary activities.

From a theoretical point of view, our research integrates literature that addresses both the firm level and the university scientist level, i.e. we draw from the knowledge spillover theory of

\footnotetext{
${ }^{1}$ In the following, we will use the term "university scientist" as shorthand for scientists employed at universities or other public research institutes.
} 
entrepreneurship (Audretsch et al., 2005; Acs et al., 2009) as well as the scientific and technical human capital approach (Bozeman and Corley, 2004; Ponomariov and Boardman, 2010) to develop our arguments on why to theoretically expect a complementary relationship between formal and informal KTT. Our empirical test rests on a comprehensive sample of more than 2,000 German manufacturing firms for which we conduct a direct test for complementarity. In that sense, our research contributes to the literature in at least two ways. First, we shed light on a rather understudied area in the literature on industry-science collaboration, i.e. the interaction of formal and informal KTT and its contribution to firm innovation performance. In contrast to other papers in the domain that focus on the individual scientist (e.g., Louis et al., 1989; Owen-Smith and Powell, 2001; 2003), we adopt the perspective of the firm engaging in university KTT. In fact, universities have frequently been regarded as a source of unique and valuable knowledge which has been characterized as the most important asset of a firm for achieving competitive advantage (Grant, 1996). Second, our research contributes to the ongoing discussion on the effectiveness of different channels of KTT to enhance firm performance and to stimulate economic growth (D'Este and Patel, 2007). In that sense, our research informs the decision making of both policy makers and managers on how to make use of particular instruments to transfer university knowledge most effectively.The remainder of the paper is organized as follows: The next section contains a theoretical discussion of the two transfer mechanisms, their interaction and the trajectories through which they may impact the innovation performance of firms. Section 3 describes our dataset and section 4 our empirical strategy. Section 5 presents our results and the final section outlines conclusions, implications of the empirical findings and limitations of our study.

\section{Literature background}

Given the multitude of channels through which knowledge and technology transfer may occur, definitions of formal versus informal modes of transfer have not been unambiguous. Link et al. (2007), for example, define informal KTT as a mechanism facilitating the flow of technology knowledge through informal communication processes which could comprise technical assistance, consulting or collaborative research. In contrast to formal KTT mechanisms which often aim at transferring a specified research outcome like a patent, informal mechanisms do not, and there is usually no expectation that they will. In this sense, formal KTT is conceived as a way to allocate property rights whereas those are of much less importance in informal KTT. This definition is however not without problems. Siegel et al. 
(2003) and Thursby et al. (2009) found that many university scientists in the US do not disclose their inventions to their university although prescribed by law. And even if university inventions are publicly disclosed some firms will try to contact scientists and set up work arrangements directly (Hall et al., 2003) purposefully by-passing the technology transfer office (Hertzfeld et al., 2006). While such a situation could be interpreted as an informal KTT, we can assume that in most cases there will at least be a contractual relationship between the scientist and the firm, governing the nature of the collaboration including duties and remuneration. The contract itself makes it hence a formal KTT. Consequently, for the purpose of our study we define informal KTT as a mechanism that does not involve any contractual relationship between the university scientist and the firm. Examples could be contacts between academics and industry personnel at conferences, or other informal contacts, talks and meetings.

Conceptually, several theoretical approaches have been suggested to explain why formal and informal KTT occur and why both modes may interact. In the following, we will focus on two approaches, namely the knowledge spillover theory of entrepreneurship as well as the scientific and technical human capital approach. We do not seek to test predictions from these theoretical approaches against each other but rather to identify arguments concerning the occurrence and interaction of formal and informal KTT. Adopting the perspective of the firm, the knowledge spillover theory of entrepreneurship has evolved as a prominent theoretical concept that puts emphasis on knowledge spillovers and their role for opportunity identification and exploitation (Audretsch et al., 2005; Acs et al., 2009). The theory argues that research and development activities lead to new knowledge being produced even though only a part of it is actually commercialized. Contexts rich in knowledge, like for example universities, generate a high number of entrepreneurial opportunities. Entrepreneurs or established firms, i.e. corporate entrepreneurs (e.g., Guth and Ginsberg, 1990), that see an opportunity in a certain piece of knowledge not fully commercialized consequently exploit the opportunity (Audretsch et al., 2005). In our context, it is the firm which therefore serves as a conduit for knowledge spillovers from academia to industry.

Knowledge produced at universities is rather basic in nature (Trajtenberg et al., 1997; Czarnitzki et al., 2009a). It can be seen as the result of a dynamic development that is hard for firms to develop internally, since this process relies on a vivid discussion of earlier research results including a careful documentation of trial and error. Nevertheless or just because of that, university science and inventions are considered to be among the most important knowledge sources for innovation activities (Cohen et al., 2002; Arundel and Geuna, 2004). 
Due to its codification and careful documentation university research can further lead to efficiency enhancement in private research and to avoiding duplicated research (Dasgupta and David, 1994; Hall et al., 2003; Crespi et al., 2006). University involvement has been further found to be especially important in new technological areas, where business partners expect university scientists to translate and explain the nature of research being undertaken and to anticipate future research problems in those areas (Hall et al., 2003, for the US Advanced Technology Program).

The choice of the KTT mode should primarily depend on the type of knowledge and its opportunities for exploitation. On the one hand, formal KTT provides the firm with a clearlycontoured research result or solution to a particular technological problem. Formal KTT through licensing for instance requires rather limited interaction. Similarly, other formal transfer modes like contract research or consulting allow firms to specify the desired research outcome which is subsequently transferred with all exploitation rights (Perkmann and Walsh, 2007). Through formal KTT firms gain access to complementary codified scientific knowledge, which they can exploit to create a unique combination of knowledge in order to enhance the quality of their inventions (Cassiman et al., 2008) or to realize efficiency gains for business R\&D (Dasgupta and David, 1994; Crespi et al., 2006). The flipside of the coin is that university licenses and other types of contracts may be sold to competitors as well, which limits the potential for creating unique and valuable combinations of firm resources (Saviotti, 1998). Further, knowledge exchange might be limited to the stipulated amount.

On the other hand, informal KTT through contacts, meetings or conferences gives a firm the opportunity to browse for relevant technological knowledge without mobilizing substantial human or financial resources. Moreover, informal KTT enables firms to access tacit knowledge surrounding formalized technological knowledge that may actually be needed in order to integrate scientific knowledge into the firm's R\&D process. To achieve this, close interaction of personnel from the university and the firm is required. Moreover, informal KTT may facilitate the attraction of talented researchers from academia who may contribute both to the quality of internal research efforts and act as 'gatekeepers' to bridge the firm's research activities with academic science (Rosenkopf and Nerkar, 2001). In this respect, Fabrizio (2009) illustrates the importance of absorptive capacity of the firm through an acquisition of scientific personnel, which leads to a better exploitation of scientific research and shorter time lags between knowledge acquisition and inventions. Although a lack of a formal collaboration framework might be considered a shortcoming of informal transfer in isolation, the 
knowledge gained from informal transfer limits competitors' opportunities for imitation (Aschhoff and Sofka, 2008).

Another theoretical approach which adopts the perspective of the individual scientist and that may consequently help explaining formal and informal modes of transfer is the scientific and technical human capital approach (Bozeman and Corley, 2004; Ponomariov and Boardman, 2010). It suggests scientific and technical human capital to be a result of 'individual endowments' of tacit and craft knowledge but also social contacts and networks. University scientists build up scientific and technical human capital as they advance their career, are productive in terms of scientific publications and patent applications, obtain external funding (Grimpe, 2012) and as they successfully collaborate with industry (Belkhodja and Landry, 2007). In addition, being well connected and occupying a key position in professional networks helps to accumulate scientific and technical human capital since "social capital begets human capital” (Ponomariov and Boardman, 2010: 616). University scientists are more likely to collaborate with industry if their endowment with scientific and technical human capital is higher because those scientists may also be better able to perform research projects together with industry. In this regard, social capital plays an important role. Establishing informal contacts between university scientists and industry personnel may 'lubricate' the relationship and increase the chance to transfer both codified and tacit knowledge such that firms get a more comprehensive understanding of the knowledge acquired from academia.

Besides the benefits that formal and informal modes of KTT individually promise, the two theoretical approaches presented above suggest that both modes may go well together (Siegel et al., 2003; Link et al., 2007). Informal contacts presumably improve the quality of a formal relationship or formal contracts may be accompanied by an informal relation of mutual exchange on technology-related aspects. It is therefore sensible to assume that, if both types occur simultaneously, codified and tacit knowledge may be transferred through the interaction between the university scientist and industry personnel (Perkmann and Walsh, 2007). Put differently, there is reason to assume a super-additive effect of formal and informal KTT on a firm's innovation performance if both modes occur simultaneously. Hence, we hypothesize a complementary relationship between formal and informal KTT, i.e. that it is not an isolated transfer mode that provides firms with superior innovation performance but instead a combination of both transfer modes. The following section introduces the empirical part of our paper. 


\section{Data}

The underlying database is the Mannheim Innovation Panel (MIP), a survey which has been conducted annually by the Centre for European Economic Research (ZEW) on behalf of the German Federal Ministry of Education and Research (BMBF) since 1992. The MIP is the German part of the Community Innovation Survey (CIS) of the European Commission. We restrict the sample to German manufacturing firms as technology transfer presumably has a different nature for services. This paper is based on the 2003 wave that asks firms whether they have collaborated with universities or public research institutes in the period from 20002002 ("Has your company collaborated with a scientific institution (university and other public science institutions) using one of the following collaboration modes in the period 20002002?”). Firms were asked to rate the importance of several KTT channels. In line with our definition of formal and informal KTT, we defined the following collaboration modes as being formal:

- collaborative research

- contract research

- technology consulting

- licensing and acquisition of technologies developed at universities

All four measures are based upon a contractual relationship. Moreover, they exhibit common characteristics in that they involve a legal contract. Hence, we summarize them under one variable for formal KTT. Informal KTT is defined by the survey item 'informal contacts to universities and public research institutes'. Out of the 2,092 firms in our sample 691 collaborated with public science in a formal and 786 in an informal way. Of those, 614 firms used both forms of collaboration while 1,229 firms did not engage in any university KTT relationship at all.

Figure 1 shows the distribution of firms across the different formal university collaboration modes. The light grey area indicates the number of firms that also have informal links to the university. The dark grey area shows firms that rely on formal links only. It becomes apparent that all types of formal collaboration modes mostly coincide with informal links to the university. Focusing on the distribution of formal collaboration modes, it seems surprising that university licensing which is receiving much attention in the literature on industryscience links is used by relatively few German firms. A likely explanation for the relatively low rate of licensing agreements between firms and universities and the high frequency of 
informal links in Germany is that until 2002 the 'professor's privilege' ('Hochschullehrerprivileg') was in place. Once derived from Article 5 of the German constitution, which pertains to the freedom of science and research, the professor's privilege constituted that professors were the only occupational group in Germany that had the right to use their scientific results for private commercialization even if the underlying research was financed by the university (Kilger and Bartenbach, 2002). The professors' right to commercialize inventions privately before 2002 is reflected by a low number of German university patents (Czarnitzki et al., 2007; 2009b; 2011), which translates into low university licensing activities in Germany as compared to the US, where the Bayh-Dole Act, which can be seen as the US counterpart of the German abolishment of the professors' privilege, took place already more than twenty years ago.

Figure 1 further shows that academic consulting is the most commonly used collaboration mode. Consulting to the business sector is an important way for scientists to increase their research budgets and has been found to be an important industry-science link for US universities as well (Link et al., 2007; Thursby et al., 2009).

The observation that formal links and informal links mostly occur together raises questions about situations in which both KTT modes occur in isolation. Formal links without informal links can for instance occur if there is a licensing contract between a firm and a university. In an extreme case, a licensing contract could happen after a patent application by the firm in which the patent examiner adds a closely related university patent as prior art. In this case, a licensing contract without additional informal links can be the consequence in order to avoid infringement. One should keep in mind that contracts are typically not written by the researchers themselves so that there might by many situations possible in which no informal links emerge. Informal links without formal links can emerge when an industry scientist visits research seminars at a university or when university researcher are invited for a presentation at a company. Another example would be a university spin-off where the founder still has close contacts to his or her former colleagues. Again, multiple scenarios are possible here. 
Figure 1: Frequency of different formal and informal links to the university

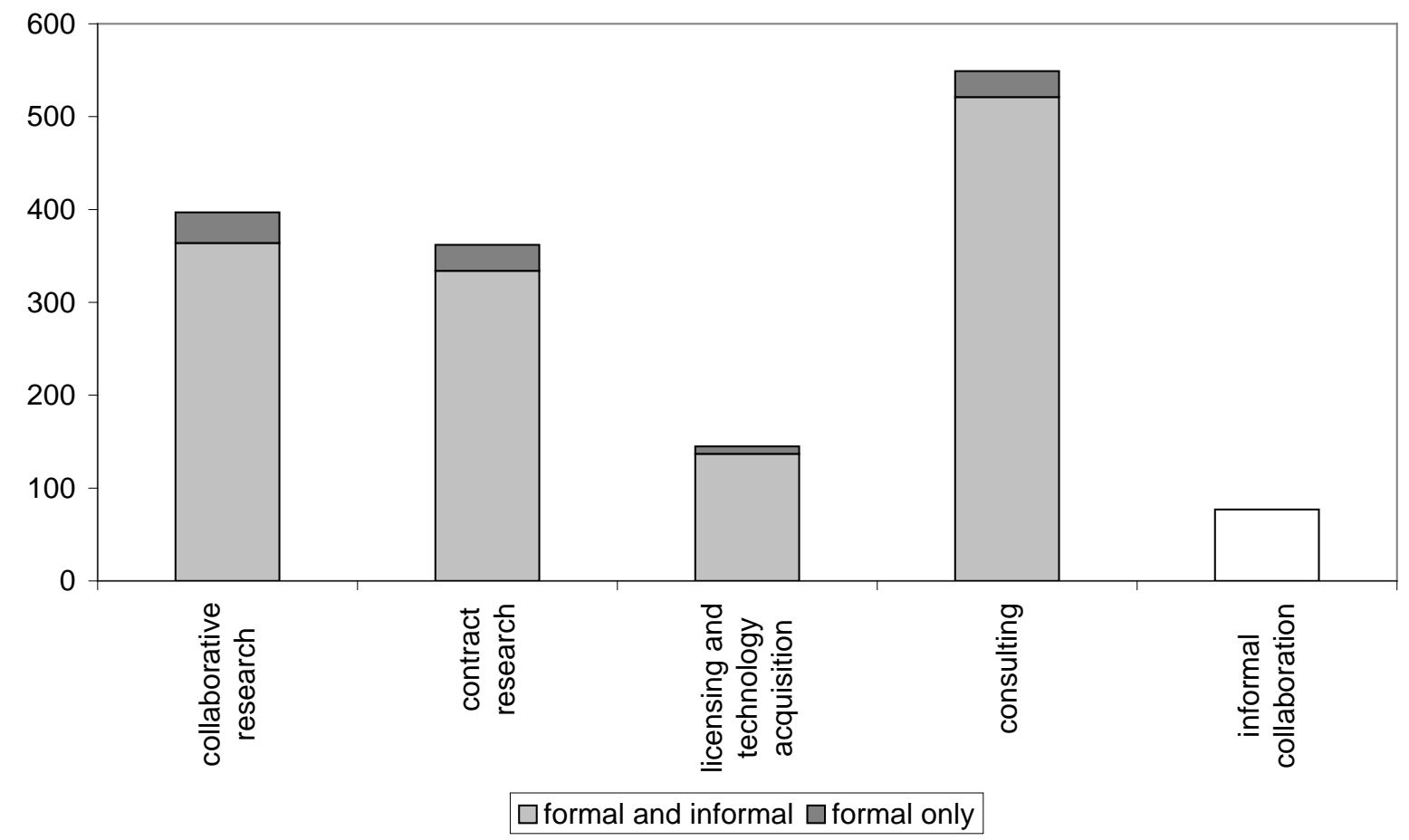

We add 'supply-side factors' in university technology transfer by matching our firm-level dataset with regional data from the year 2000 on the number of university scientists in the NUTS-3 region where the firm is located. We did not restrict this number to any particular scientific discipline but normalized it by dividing it by the population of the region. Table 5 in the appendix summarizes the definitions of the control variables.

Table 1 shows some descriptive statistics distinguishing between the four groups of firms according to their involvement in collaboration with scientific institutions. ${ }^{2}$ It becomes apparent that firms engaged in formal and informal KTT are the largest in terms of employment, R\&D intensity, innovation sales over total sales ${ }^{3}$, share of skilled workers, as defined by labor force with a university degree, and export sales. The high R\&D intensity of firms using both modes of KTT suggests that firms require substantial absorptive capacity (Cohen and Levinthal, 1989; 1990) in order to reap the benefits from formal and informal university collaboration. Skilled labor as defined by employees with a university degree might be essential not only for the exploitation of formal relationships but much more for the establishment of informal contacts to the university. The higher innovation sales of firms

\footnotetext{
${ }^{2}$ The definition of the industry classification can be found in Table 4 in the appendix.

${ }^{3}$ Note that the percentage of innovation sales is derived from the last three years.
} 
using both transfer modes are a first indication for the complementarity of formal and informal university links.

Note that for the continuous variables Table 1 shows the means and standard deviations for two different years. We use the continuous variables as firm size and R\&D intensity with a one year lag in our later regression for the choice of the collaboration modes in order to limit endogeneity problems with respect to the regressors. For the same reason we linked the crosssection 2003 to the cross-section 2004. In the last part of the analysis we estimate the effect of the different transfer mechanisms on innovation sales. Using a lead of the dependent variable is again an attempt to limit endogeneity problems. Unfortunately, only a subsample of 884 firms responded to the sample in both years, which reduces the number of observations in the last part of the analysis. 


\begin{tabular}{|c|c|c|c|c|c|c|c|c|c|c|c|c|}
\hline & \multicolumn{3}{|c|}{ Formal collaboration only } & \multicolumn{3}{|c|}{ Informal collaboration only } & \multicolumn{3}{|c|}{$\begin{array}{c}\text { Formal and informal } \\
\text { collaboration }\end{array}$} & \multicolumn{3}{|c|}{ No collaboration } \\
\hline & \# obs. & mean & std. dev. & \# obs. & mean & std. dev. & \# obs. & mean & std. dev. & \# obs. & mean & std. dev. \\
\hline R\&D/employment 2002 & 77 & 0.01 & 0.03 & 172 & 0.01 & 0.01 & 613 & 0.02 & 0.03 & 1230 & 0.00 & 0.01 \\
\hline R\&D/employment 2001 & 77 & 0.01 & 0.02 & 172 & 0.01 & 0.01 & 613 & 0.02 & 0.03 & 1230 & 0.00 & 0.01 \\
\hline Innovation sales/total sales 2003 & 40 & 18.45 & 29.14 & 84 & 16.12 & 22.62 & 297 & 25.29 & 27.18 & 568 & 9.44 & 18.67 \\
\hline Innovation sales/total sales 2002 & 77 & 16.77 & 25.61 & 172 & 17.81 & 23.70 & 613 & 23.10 & 26.53 & 1230 & 10.66 & 20.33 \\
\hline I(Innovation sales/employment $\left.{ }_{2003}>0\right)$ & 40 & 0.50 & 0.51 & 84 & 0.55 & 0.50 & 297 & 0.75 & 0.43 & 568 & 0.38 & 0.49 \\
\hline I(Innovation sales/employment $2002>0)$ & 77 & 0.38 & 0.49 & 172 & 0.33 & 0.47 & 613 & 0.52 & 0.50 & 1230 & 0.20 & 0.40 \\
\hline Share of skilled labor force 2002 & 77 & 19.10 & 22.21 & 172 & 16.36 & 16.33 & 613 & 23.18 & 21.85 & 1230 & 12.55 & 12.24 \\
\hline No. of skilled workers 2002 & 77 & 0.04 & 0.19 & 172 & 0.05 & 0.21 & 613 & 0.02 & 0.15 & 1230 & 0.16 & 0.37 \\
\hline Skilled labor force/R\&D 2002 & 77 & 28.60 & 43.53 & 172 & 24.04 & 34.64 & 613 & 33.93 & 230.13 & 1230 & 77.02 & 666.52 \\
\hline Share of skilled labor force 2001 & 77 & 17.58 & 22.05 & 172 & 16.28 & 16.47 & 613 & 22.45 & 21.85 & 1230 & 12.19 & 12.20 \\
\hline No. of skilled workers 2001 & 77 & 0.06 & 0.25 & 172 & 0.05 & 0.20 & 613 & 0.02 & 0.15 & 1230 & 0.17 & 0.37 \\
\hline Employment $_{2002}$ & 77 & 270.23 & 681.92 & 172 & 298.98 & 689.48 & 613 & 2941.44 & 21127.83 & 1230 & 250.66 & 1126.84 \\
\hline Employment $_{2001}$ & 77 & 293.59 & 715.46 & 172 & 334.88 & 695.37 & 613 & 3069.75 & 23108.83 & 1230 & 252.68 & 1011.77 \\
\hline Product innovator & 77 & 0.62 & 0.49 & 172 & 0.65 & 0.48 & 613 & 0.85 & 0.36 & 1230 & 0.44 & 0.50 \\
\hline Process innovator & 77 & 0.40 & 0.49 & 172 & 0.41 & 0.49 & 613 & 0.57 & 0.50 & 1230 & 0.30 & 0.46 \\
\hline Scientists per 1000 inhabitants in region $_{2000}$ & 77 & 2.29 & 5.15 & 172 & 2.58 & 5.16 & 613 & 3.55 & 5.65 & 1230 & 2.20 & 4.78 \\
\hline Export sales $_{2002}$ & 77 & 62.15 & 187.56 & 172 & 50.33 & 90.01 & 613 & 746.87 & 6946.96 & 1230 & 54.22 & 200.10 \\
\hline Export sales $_{2001}$ & 77 & 72.80 & 189.34 & 172 & 71.67 & 116.67 & 613 & 762.53 & 6937.55 & 1230 & 65.47 & 215.41 \\
\hline East Germany & 77 & 0.31 & 0.47 & 172 & 0.32 & 0.47 & 613 & 0.31 & 0.46 & 1230 & 0.30 & 0.46 \\
\hline Firm age & 77 & 14.57 & 13.28 & 172 & 18.48 & 15.34 & 613 & 25.35 & 83.76 & 1230 & 19.23 & 17.22 \\
\hline Part of a firm group & 77 & 0.43 & 0.50 & 172 & 0.46 & 0.50 & 613 & 0.53 & 0.50 & 1230 & 0.51 & 0.50 \\
\hline ... with a headquarter outside of Germany & 77 & 0.16 & 0.37 & 172 & 0.13 & 0.34 & 613 & 0.15 & 0.36 & 1230 & 0.06 & 0.23 \\
\hline Industry 1 & 77 & 0.16 & 0.37 & 172 & 0.12 & 0.32 & 613 & 0.06 & 0.24 & 1230 & 0.16 & 0.36 \\
\hline Industry 2 & 77 & 0.04 & 0.19 & 172 & 0.03 & 0.17 & 613 & 0.01 & 0.11 & 1230 & 0.05 & 0.21 \\
\hline Industry 3 & 77 & 0.12 & 0.32 & 172 & 0.15 & 0.35 & 613 & 0.17 & 0.38 & 1230 & 0.13 & 0.34 \\
\hline Industry 4 & 77 & 0.08 & 0.27 & 172 & 0.03 & 0.18 & 613 & 0.06 & 0.24 & 1230 & 0.05 & 0.21 \\
\hline Industry 5 & 77 & 0.16 & 0.37 & 172 & 0.15 & 0.36 & 613 & 0.12 & 0.33 & 1230 & 0.17 & 0.38 \\
\hline Industry 6 & 77 & 0.16 & 0.37 & 172 & 0.16 & 0.36 & 613 & 0.18 & 0.38 & 1230 & 0.13 & 0.34 \\
\hline Industry 7 & 77 & 0.22 & 0.42 & 172 & 0.23 & 0.42 & 613 & 0.27 & 0.44 & 1230 & 0.14 & 0.34 \\
\hline Industry 8 & 77 & 0.05 & 0.22 & 172 & 0.09 & 0.29 & 613 & 0.11 & 0.31 & 1230 & 0.12 & 0.32 \\
\hline
\end{tabular}




\section{Empirical strategy: Testing for complementarity}

In order to test for complementarity of formal and informal links to the university we apply an empirical strategy that is based on the theory of supermodularity (Milgrom and Roberts, 1995; Arora, 1996; Athey and Stern, 1998; Lokshin et al., 2004) which has been used in the field of industrial organization and management in recent years (e.g., Kaiser, 2003; Lokshin et al., 2004; Mohnen and Röller, 2005; Cassiman and Veugelers, 2006; Catozzella and Vivarelli, 2007). In these contexts, complementarity is defined as the increase in marginal or incremental return to one practice if other practices are in use as well. In our application we are interested in testing whether the use of informal university KTT increases the returns of formal KTT or vice-versa. Intuitively, this means that using the second channel of collaboration if the other one is in place has a higher incremental impact on innovation performance than using one of the modes more intensely in isolation. Analogously, we would find that informal and formal KTT are substitutes if one of the links would decrease the marginal or incremental returns from one to the other collaboration mode. We will use a direct test for supermodularity in the empirical section (Arora, 1996; Athey and Stern, 1998). The direct approach tests whether the simultaneous adoption of different practices, formal and informal KTT, has a positive impact on innovation performance. If the joint use of both collaboration modes has the highest impact as compared to using one of the channels in isolation they are complements (Arora, 1996; Athey and Stern, 1998; Lokshin et al., 2004; Mohnen and Röller, 2005; Cassiman and Veugelers, 2006; Catozzella and Vivarelli, 2007). In the empirical application we have hence three different possible collaboration patterns for each firm $i$, formal collaboration (A1), informal collaboration (A2), and both informal and formal collaboration $\left(A 1^{*} A 2\right)$, entering our empirical model for the innovation performance at the firm level:

$I\left(A 1_{i}, A 2_{i}, X_{i}\right)=A 1_{i}^{*} b_{10}+A 2_{i}^{*} b_{01}+A 1_{i} * A 2_{i} * b_{11}+X_{i} \beta+u_{i}$

The direct test derives directly from the inequality defined by the theory on supermodularity (Milgrom and Roberts, 1995). In case of complementarity we should find:

$b_{11} \geq b_{10}+b_{01}$

\section{Empirical Results}

Before we apply a direct test to investigate complementarity between formal and informal KTT, we analyze the correlation between both collaboration modes conditional on absorptive 
capacity and other characteristics of the firm. Formal and informal KTTs is defined as nonexclusive activities of the firms, i.e. it is possible that the firms use both. We estimate the following bivariate probit model:

$$
\begin{aligned}
& \text { formal }_{i}=Z_{i} \beta+u_{i 1}, \text { formal }_{i}= \begin{cases}1 & \text { if } \text { formal }_{i} \\
0 & \text { otherwise }\end{cases} \\
& \text { informal }_{i}=Z_{i} \beta+u_{i 2}, \text { informal }_{i}=\left\{\begin{array}{ll}
1 & \text { if } \text { formal }_{i}^{*}>0 \\
0 & \text { otherwise }
\end{array}\right. \text {, } \\
& E\left[u_{i 1}\right]=E\left[u_{i 2}\right]=0, \operatorname{Var}\left[u_{i 1}\right]=\operatorname{Var}\left[u_{i 2}\right]=1, \operatorname{Cov}\left[u_{i 1}, u_{i 2}\right]=\rho
\end{aligned}
$$

where $Z_{i}$ is a vector of firm characteristics.

The results are presented in Table 2. The most important finding is that there is a significant positive relationship between formal and informal KTT as indicated by the positive and significant correlation coefficient $\rho$. This finding suggests that formal and informal links are likely to occur in combination and is hence a first indication of complementarity. The estimation results further show that there is no substantial heterogeneity in firm characteristics predicting formal and informal KTT. In line with our expectations, firm size and absorptive capacity as is reflected by $R \& D$ intensity are important to engage in any technology transfer from the university while firm age reduces the propensity to engage in formal KTT. The negative effect of firm age might be explained by the fact that the firm was founded based on a patent or license originating from a university. In case of a university spin-off we can also assume this relationship to continue after the firm was founded. Moreover, one could assume that with increasing age, a firm is more capable of doing reseach in-house. In contrast, we do find a positive effect of firm size which rather captures the effect that large firms have more funds available to invest into $R \& D$ and into $R \& D$ collaboration. Moreover, skilled workers (normalized by R\&D) matter significantly and having no employees with a university degree significantly lowers the probability of using either one KTT mode from the university. Employees with a university degree are supposed to be essential for establishing and maintaining contacts to the university. Further, the density of scientists in the region is an important determinant for KTT from the university. Moreover, firms being part of a firm group are less engaged in university collaboration be it formal or informal. This effect is less strong for firm groups with a foreign headquarter. A likely explanation is that firm groups give priority to collaboration within the group and that firm groups with a foreign headquarter might be more interested in learning about local 
technologies than domestically led firm groups. Lastly, Eastern German firms turn out to be more likely to collaborate with universities.

The only difference for the predictors of using formal versus informal links to the university is found in the age of firms. While the likelihood of formal KTT decreases in firm age there is no significant effect for the use of informal technology transfer. ${ }^{4}$

Table 2: Bivariate probit estimation for the choice of formal and informal KTT

\begin{tabular}{|c|c|c|c|c|c|c|}
\hline \multirow[b]{3}{*}{ Log(employment 2001 ) } & \multicolumn{3}{|c|}{ Formal KTT } & \multicolumn{3}{|c|}{ Informal KTT } \\
\hline & \multicolumn{2}{|c|}{ coefficient } & \multirow{2}{*}{$\frac{\text { std. err. }}{0.03}$} & \multicolumn{2}{|c|}{ coefficient } & \multirow{2}{*}{$\frac{\text { std. err. }}{0.03}$} \\
\hline & 0.15 & $* * *$ & & 0.13 & $* * *$ & \\
\hline East Germany $_{2002}$ & 0.14 & $* *$ & 0.07 & 0.15 & $* *$ & 0.07 \\
\hline $\log ($ firm age 2002$)$ & -0.08 & $* *$ & 0.04 & -0.03 & & 0.04 \\
\hline $\log \left(\right.$ export $\left._{2001}\right)$ & 0.04 & $* *$ & 0.02 & 0.05 & $* * *$ & 0.02 \\
\hline R\&D/employment 2001 & 10.46 & $* * *$ & 2.07 & 9.08 & $* * *$ & 2.08 \\
\hline No skilled workers & -0.38 & $* * *$ & 0.14 & -0.52 & $* * *$ & 0.14 \\
\hline Log(Skilled workers/R\&D 2001$)$ & 0.03 & $* * *$ & 0.00 & 0.03 & $* * *$ & 0.00 \\
\hline Product innovator 2002 & 0.40 & $* * *$ & 0.08 & 0.38 & $* * *$ & 0.08 \\
\hline Process innovator $_{2002}$ & 0.16 & $* *$ & 0.07 & 0.15 & $* *$ & 0.07 \\
\hline Log(scientists per capita 2000 ) & 0.01 & $* * *$ & 0.01 & 0.01 & $* * *$ & 0.01 \\
\hline Part of a firm group 2002 & -0.64 & $* * *$ & 0.08 & -0.64 & * & 0.08 \\
\hline ... with a headquarter outside of Germany 2002 & 0.58 & $* * *$ & 0.11 & 0.59 & $* * *$ & 0.11 \\
\hline Industry 1 & -0.01 & & 0.13 & -0.13 & & 0.12 \\
\hline Industry 2 & -0.08 & & 0.21 & -0.18 & & 0.20 \\
\hline Industry 3 & 0.23 & * & 0.12 & 0.18 & & 0.12 \\
\hline Industry 4 & 0.66 & $* * *$ & 0.16 & 0.42 & $* * *$ & 0.16 \\
\hline Industry 5 & 0.18 & & 0.12 & 0.09 & & 0.11 \\
\hline Industry 6 & 0.23 & $*$ & 0.12 & 0.14 & & 0.11 \\
\hline Industry 7 & 0.31 & $* * *$ & 0.11 & 0.25 & $* *$ & 0.11 \\
\hline constant & -1.09 & $* * *$ & 0.19 & -0.85 & $* * *$ & 0.19 \\
\hline$\rho$ & 0.88 & $* * *$ & 0.14 & & & \\
\hline Number of observations & 2092 & & & & & \\
\hline Wald-X ${ }^{2}$ & 609.27 & $* * *$ & & & & \\
\hline
\end{tabular}

In the next step we conduct a direct test for complementarity of both KTT modes. We test whether the combined use of both translates into superior innovation performance. Our R\&D performance measure is sales with innovative products, defined as products new to the market over total sales. We use the dependent variable with a one-year lead to limit endogeneity problems. As not all firms responded to the survey in the following year we have

\footnotetext{
${ }^{4}$ We checked if the negative effect of firm age is driven by our specification by including a squared term of the age variable. Both the linear and the squared term were significant, the linear with a negative and the squared term with a positive sign. This would suggest a U-shaped relationship. However, the turning point lies to the right of the data cloud so that this finding actually supports a negative relationship between the use of formal technology transfer channels and firm age. It has to be noted that the effect of firm age is distinct from the effect of firm size since the two variables measure two different dimensions, with mature firms not necessarily being large and vice versa. The low correlation of 0.19 between the variables supports this perspective.
} 
to conduct the test based on a reduced number of observations. The test is implemented using a tobit model to account for the fact that many firms have no sales with innovative products at all and others that have all their sales with innovative products. The estimated model can be written as:

$$
\frac{\text { innovation sales }_{i}^{*}}{\text { total sales }_{i}}=b_{10} \text { informal }_{i}+b_{01} \text { formal }_{i}+b_{11}\left(\text { informal }_{i} * \text { formal }_{i}\right)+\beta X_{i}+u_{i},
$$

where $\frac{\text { innovation sales }_{i}{ }^{*}}{\text { total sales }_{i}}$ is the unobserved latent variable. The observed dependent variable is equal to:

$$
\frac{\text { innovation sales }_{i}}{\text { total sales }_{i}}=\left\{\begin{array}{cl}
1 & \text { if } \frac{\text { innovation sales }_{i}^{*}}{\text { total sales }_{i}} \geq 1 \\
\frac{\text { innovation sales }_{i}}{\text { total sales }_{i}} & \text { if } 0<\frac{\text { innovation sales }_{i}}{\text { total sales }_{i}}<1 \\
0 & \text { if } \frac{\text { innovation sales }_{i}^{*}}{\text { total sales }_{i}} \leq 0
\end{array}\right.
$$

Most important the coefficients for the informal and formal variable and the interaction term of those variables as they allow to directly test equation (2). $X_{i}$ is a vector of covariates and $u_{i}$ the error term of the model.

In addition, we estimate a probit model in search of complementarity of both KTT modes for the likelihood of having any innovation sales as a robustness check. The dependent variable is now a binary variable that equals one if innovation sales are larger than zero and zero otherwise. The model can be written as:

I innovation sales $\left._{i}>0\right]^{*}=b_{10}$ informal $_{i}+b_{01}$ formal $_{i}+b_{11}\left(\right.$ informal $_{i} *$ formal $\left._{i}\right)+\beta X_{i}+u_{i}$

$I\left[\right.$ innovation sales $\left._{i}>0\right]= \begin{cases}1 & \left.\text { if I }{\text { innovation } \text { sales }_{i}}^{*}>0\right] \geq 0 \\ 0 & \text { otherwise }\end{cases}$

Table 3 shows the estimation results. The results of both models show that using formal and informal KTT in combination contributes to firms' innovation performance, while there is no performance effect of using one KTT mode in isolation. This is a strong indication for complementarity of formal and informal KTT. We can further confirm this result based on 
one-sided tests on the null hypothesis of no complementarity (derived from equation (2)) at the $10 \%$ level of statistical significance (see bottom of Table 3$).^{5}$

With respect to the control variables, it turns out that the major part of innovation sales over total sales is explained by innovation sales over total sales in the previous period. This is not surprising as the lagged dependent variable can be seen as an attempt to control for fixed effects in innovation performance. A few other variables have an effect on innovation sales. One is the indicator for R\&D collaborations with firms. Like industry-science linkages, interfirm collaborations have a positive effect on innovation sales confirming prior findings (see Hagedoorn, 2002, for an overview). Further, the share of workers with a university degree and being a process innovator are predictors of innovation sales. SMEs and firms in firm groups with a foreign headquarter are less successful in terms of innovation output than others.

\footnotetext{
${ }^{5}$ Note that the low levels of significance for the coefficients for informal and formal KTT are caused by their high correlation indicated by a correlation coefficient of 0.74 . This suggests that with different, less correlated measures for the individual KTT links the coefficients might become significant so that their non-significance should not be overinterpreted.
} 
Table 3: Tobit and probit models for the effects of different university collaboration modes on innovation sales

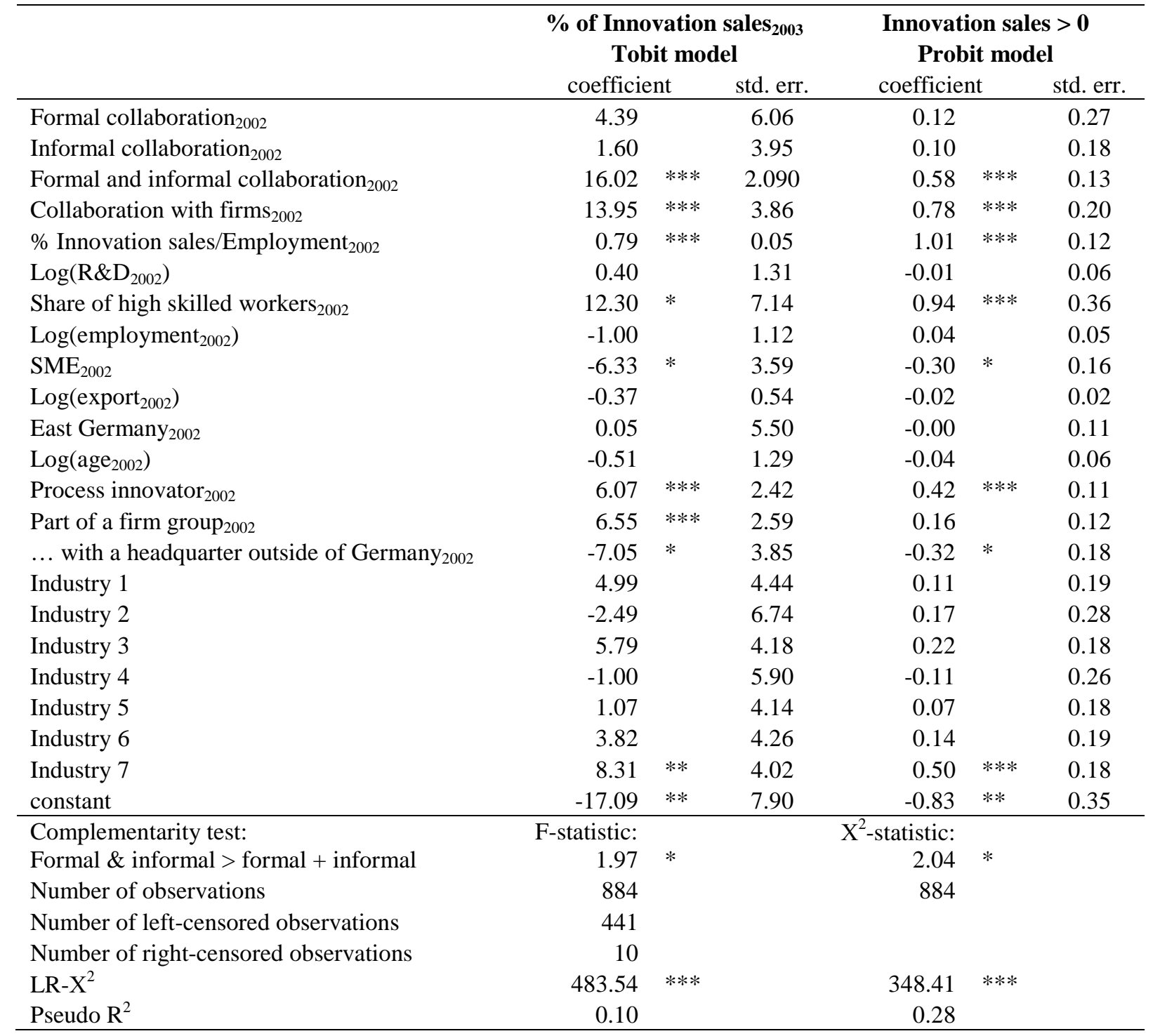

\section{Conclusion and future research}

In this paper, we have analyzed the interplay of formal and informal university KTT modes and their importance for innovation performance of firms. We defined informal KTT as a mechanism that does not involve a contractual relationship between the university scientist and the firm while formal KTT is based on such a contract. Our research has used the knowledge spillover theory of entrepreneurship (Audretsch et al., 2005; Acs et al., 2009) and the scientific and technical human capital approach (Bozeman and Corley, 2004; Ponomariov and Boardman, 2010) to explain both modes as well as their interaction. In fact, our empirical analysis reveals that the use of formal and informal KTT with the university mostly 
coincides. Complementarity tests show that formal and informal modes are complements, i.e. the use of informal KTT is associated with higher marginal returns of formal KTT and vice versa.

In that sense, our results contribute to the literature by shedding light on an understudied area in the literature on industry-science collaboration. We adopt the perspective of the firm engaging in university KTT to show that knowledge which has not yet been commercialized may be exploited by corporate entrepreneurs in order to increase innovation performance. Moreover, our research informs the decision making of both policy makers and managers on how to make use of particular instruments to transfer university knowledge most effectively. Our analysis reveals, for instance, that university licensing is not as prominent in Germany as previous literature suggests for the US. The reason is that until 2002 professors owned the inventions they produced at German universities ('professor's privilege'). Hence, we observe only a few technologies that are patented through German universities, which leads to little opportunities for university licensing. From 2003 on, the professor's privilege was abolished and since then universities own the inventions made in-house and have, hence, only since then been in charge of KTT. For the German university system, this means a significant change as universities mostly did not maintain professional technology transfer offices (TTOs) like US universities (Debackere and Veugelers, 2005). As a consequence, TTOs just emerged in Germany in recent years. TTOs typically support formal KTT between universities and the business sector. Our findings suggest that universities should keep in mind the importance of informal transfer which is already in place when designing KTT policies and commercialization incentive schemes for scientists. Next to fostering contracting with the business sector, room for informal contacts should be established and existing informal links should be identified, acknowledged and supported by TTOs if they are considered useful for the university.

Our results also have important management implications. First, firms interested in setting up a relationship with a university to transfer knowledge and technology should be aware that the full potential of such a transfer can only be realized if both transfer channels are used. The reasons for this are twofold: Firms do not only require the codified knowledge, e.g. in a licensed patent, but also the tacit knowledge surrounding a particular technology. In this sense, establishing a permanent relationship with a university with varying degrees of formality or informality seems to be key in benefiting from knowledge developed externally 
at universities. Moreover, our empirical analysis highlights the importance of absorptive capacity for KTT and its exploitation within the firm.

Our study is not without limitations. First of all, our data are based on a cross-section which limits our ability to infer causal effects. Nevertheless, we have used different survey waves to limit simultaneity problems. Moreover, it would, for instance, be interesting to investigate the different formal KTT modes and their complementarity with informal modes in isolation. Given the small numbers of firms that use only formal KTT modes our data does not allow us to provide additional analyses here. Lastly, we focus on manufacturing firms only. It would be interesting to extent the analysis to service firms. However, such an analysis would be complicated by the different nature of innovation processes in manufacturing versus services sectors. Future research should try to generate more insights on how formal and informal KTT mechanisms can be combined such that both sides benefit most. In this respect, it would particularly be interesting, on the one hand, to get insights on the evolution of KTT relationships, whether both channels can be observed at the same time or whether one channel stimulates the other. Relatedly, it would be very interesting to investigate the emergence of formal and informal links around universities and how university's business networks evolve. On the other hand, it would be interesting for the case of Germany to conduct a similar analysis in a couple of years in order to evaluate the effect of the abolishment of the professor's privilege on formal and informal KTT. Further, with a richer dataset moderation effects that explain under which conditions complementarity is stronger or weaker could be identified. 


\section{References}

Acs, Z.A., P. Braunerhjelm, D.B. Audretsch and B. Carlsson (2009), The Knowledge Spillover Theory of Entrepreneurship, Small Business Economics 32, 15-30.

Adams, J.D. (1990), Fundamental Stocks of Knowledge and Productivity Growth, Journal of Political Economy 98, 673-702.

Aerts, K., P. Matthyssens and K. Vandenbempt (2007), Critical Role and Screening Practices of European Business Incubators, Technovation 27, 254-267.

Arora, A. (1996), Testing for Complementarities in Reduced-Form Regressions: A Note, Economics Letters 50, 51-55.

Arrow, K.J. (1962), Economic Welfare and the Allocation of Resources for Invention, in: Nelson, R. R. (ed.) The Rate and Direction of Inventive Actvitiy: Economic and Social Factors, Princeton, NJ, 609-625.

Arundel, A. and A. Geuna (2004), Proximity and the Use of Public Science by Innovative European Firms, Economics of Innovation and New Technologies 13 (6), 559-580.

Aschhoff, B. and W. Sofka (2008), Successful Patterns of Scientific Knowledge Sourcing Mix and Match, ZEW Discussion Paper No. 08-033, Mannheim.

Athey, S. and S. Stern (1998), An Empirical Framework for Testing Theories About Complementarity in Organizational Design, NBER Working Paper No. 6600, Boston.

Audretsch, D.B., M. Keilbach and E. Lehmann (2005), The Knowledge Spillover Theory of Entrepreneurship and Technological Diffusion, in: University Entrepreneurship and Technology Transfer: Process, Design, and Intellectual Property, Advances in the Study of Entrepreneurship, Innovation and Economic Growth, 16, 69-91.

Barney, J.B. (1991), Firm Resources and Sustained Competitive Advantage, Journal of Management 17 (1), 99-120.

Bowman, E.H. and D. Hurry (1993), Strategy through the Option Lens: An Integrated View of Resource Investments and The, Academy of Management Review 18 (4), 760-782.

Bozeman, B. (2000), Technology Transfer and Public Policy: A Review of Research and Theory, Research Policy 29, 627-655.

Bozeman, B. and E. Corley (2004), Scientists' Collaboration Strategies: Implications for Scientific and Technical Human Capital, Research Policy 33 (4), 599-616.

Cassiman, B. and R. Veugelers (2006), In Search of Complementarity in the Innovation Strategy: Internal R\&D and External Knowledge Acquisition, Management Science 52 (1), 68-82.

Cassiman, B., R. Veugelers and P. Zungia (2007), Science Linkages and Innovation Performance: An Analysis on Cis-3 Firms in Belgium, IESE Business School University of Navarra No., Barcelona.

Cassiman, B., R. Veugelers and M.P. Zuniga (2008), In Search of Performance Effects of (in)Direct Industry Science Links, Industrial \& Corporate Change 17, 611-646.

Catozzella, A. and M. Vivarelli (2007), The Catalysing Role of in-House R\&D in Fostering the Complementarity of Innovative Inputs, IZA Discussion Paper No. 3126, Bonn.

Cockburn, I.M. and R.M. Henderson (1998), Absorptive Capacity, Coauthoring Behavior, and the Organization of Research in Drug Discovery, Journal of Industrial Economics 46 (2), 157-182.

Cohen, W.M. and D.A. Levinthal (1989), Innovation and Learning: The Two Faces of R\&D, The Economic Journal 99 (397), 569-596.

Cohen, W.M. and D.A. Levinthal (1990), Absorptive Capacity: A New Perspective on Learning and Innovation, Administrative Science Quarterly 35 (1), 128-153. 
Cohen, W.M., R.R. Nelson and J.P. Walsh (2002), Links and Impacts: The Influence of Public Research on Industrial R\&D, Management Science 48 (1), 1-23.

Crespi, G.A., A. Geuna and B. Verspagen (2006), University IPRs and Knowledge Transfer. Is the IPR Ownership Model More Efficient?, SEWPS (SPRU Electronic Working Paper Series) No. 154, Brighton.

Czarnitzki, D., W. Glänzel and K. Hussinger (2007), Patent and Publication Activities of German Professors: An Empirical Assessment of Their Co-Activity, Research Evaluation 16 (4), 311-319.

Czarnitzki, D., K. Hussinger and C. Schneider (2009a), Why Challenge the Ivory Tower? New Evidence on the Basicness of Academic Patents, Kyklos 62(4): 488-499.

Czarnitzki, D., W. Glänzel and K. Hussinger (2009b), Heterogeneity of Patenting and Implications for Basic Research, Research Policy 38: 26-34.

Czarnitzki, D., K. Hussinger and C. Schneider (2011), Commercializing Academic Research: The Quality of Faculty Patenting, Industrial and Corporate Change 20(5): 14031437.

Czarnitzki, D., K. Hussinger and C. Schneider (2012), The Nexus between Science and Industry: Evidence from Faculty Inventions, Journal of Technology Transfer 37(5): 755-776.

D'Este, P. and P. Patel (2007), University-Industry Linkages in the Uk: What Are the Factors Underlying the Variety of Interactions with Industry?, Research Policy 36 (9), 12951313.

Dasgupta, P. and P. David (1994), Towards a New Economics of Science, Research Policy 3, 487-521.

De Bondt, R. (1996), Spillovers and Innovation Activities, International Journal of Industrial Organization 15, 1-28.

Debackere, K. and R. Veugelers (2005), The Role of Academic Technology Transfer Organizations in Improving Industry-Science Links, Research Policy 34 (3), 321-342.

Fabrizio, K. (2009), Absorptive Capacity and Innovation: Evidence from Pharmaceutical and Biotechnology Firms, Research Policy 38(2), 255-267.

Feldman, M.P., I. Feller, J. Bercovitz and R. Burton (2002), Equity and the Technology Transfer Strategies of American Research Universities, Management Science 48, 105121.

Gambardella, A. (1995), Science and Innovation: The Us Pharmaceutical Industry During the 1980s, Cambridge, MA.

Gemünden, H., M. Heydebreck and R. Wijnberg (1992), Technological Interweavement: A Means of Achieving Innovation Success, R\&D Management 22 (4), 359-376.

Guth, W.D. and A. Ginsberg (1990), Guest Editor's Introduction: Corporate Entrepreneurship, Strategic Management Journal 11, 5-15.

Grant, R.M. (1996), Toward a Knowledge-Based Theory of the Firm, Strategic Management Journal 17, 109-122.

Grimpe, C. and Fier, H. (2010), Informal University Technology Transfer: A Comparison Between the United States and Germany, Journal of Technology Transfer 35: 637650.

Grimpe, C. (2012), Extramural Research Grants and Scientists’ Funding Strategies: Beggars Can't Be Choosers?, Research Policy 41, 1448-1460.

Hagedoorn, J. (2002), Inter-Firm R\&D Partnerships. An Overview of Major Trends and Patterns since 1960, Research Policy 31 (4), 477-492.

Hall, B.H., A.N. Link and J.T. Scott (2003), Universities as Research Partners, Journal of Economic Studies 85, 485-491. 
Henderson, R. and I. Cockburn (1994), Measuring Competence? Exploring Firm Effects in Pharmaceutical Research, Strategic Management Journal 15 (8), 63-84.

Hertzfeld, H.R., Link, A.N., Vonortas, N.S. (2006), Intellectual Property Protection Mechanisms in Research Partnerships. Research Policy 35, 825-838.

Jaffe, A. (1989), The Real Effects of Academic Research, American Economic Review 97 (5), 957-970.

Jaffe, A.B. (1986), Technological Opportunity and Spillovers of R\&D: Evidence from Firms' Patents, Profits, and Market Values, American Economic Review 76 (5), 984-1001.

Jensen, R.A. and M.C. Thursby (2001), Proofs and Prototypes for Sale: The Licensing of University Inventions, American Economic Review 91, 240-259.

Kaiser, U. (2003), Strategic Complementarities between Different Types of Ict-Expenditures, ZEW Discussion Paper No. 03-46, Mannheim.

Kilger, C. and K. Bartenbach (2002), New Rules for German Professors, Science 298 (8), 1173-1175.

Kuemmerle, W. (1998), Optimal Scale for Research and Development in Foreign Environments: An Investigation into Size and Performance of Research and Development Laboratories Abroad, Research Policy 27, 111-126.

Link, A.N. (1996), Research Joint Ventures: Patterns from Federal Register Filings, Review of Industrial Organization 11, 617-628.

Link, A.N. and J.T. Scott (2005), Universities as Partners in U.S. Research Joint Ventures, Research Policy 34, 385-393.

Link, A.N., D.S. Siegel and B. Bozeman (2007), An Empirical Analysis of the Propensity of Academics to Engage in Informal University Technology Transfer, Industrial \& Corporate Change 16 (4), 641-655.

Lokshin, B., M. Carree and R. Belderbos (2004), Testing for Complementarity and Substitability in Case of Multiple Practices, KU Leuven No. mimeo.

Louis, K.S., D. Blumenthal, M.E. Gluck and M.A. Stoto (1989), Entrepreneurs in Academe: An Exploration of Behaviors among Life Scientists, Administrative Science Quaterly 34, 110-131.

Merton, R.K. (1973), The Normative Structure of Science, in: Merton, R. K. (ed.) The Sociology of Science: Theoretical and Empirical Investigations, Chicago, IL.

Milgrom, P. and J. Roberts (1995), Complementarities and Fit: Strategy, Structure and Organizational Change in Manufacturing, Journal of Accounting and Economics 19, 179-208.

Mohnen, P. and L.-H. Röller (2005), Complementarities in Innovation Policy, European Economic Review 49, 1431-1450.

Nadiri, I.M. (1993), Innovations and Technological Spillovers., NBER Working Paper No. 4423, Cambridge, MA.

Owen-Smith, J. and W.W. Powell (2001), To Patent or Not: Faculty Decisions and Institutional Success at Technology Transfer, Journal of Technology Transfer 26, 99114.

Owen-Smith, J. and W.W. Powell (2003), The Expanding Role of University Patenting in the Life Sciences: Assessing the Importance of Experience and Connectivity, Research Policy 32, 1695-1711.

Perkmann, M. and K. Walsh (2007), University-Industry Relationships and Open Innovation: Towards a Research Agenda, International Journal of Management Reviews 9 (4), 259-280.

Ponomariov, B.L. and P.C. Boardman (2010), Influencing Scientists' Collaboration and Productivity Patterns through New Institutions: University Research Centers and Scientific and Technical Human Capital, Resarch Policy 39, 613-624. 
Rothaermel, F.T., S.D. Agung and L. Jiang (2007), University Entrepreneurship: A Taxonomy of the Literature, Industrial \& Corporate Change 16 (4), 691-791.

Saviotti, P.P. (1998), On the Dynamics of Appropriability, of Tacit and of Codified, Research Policy 26 (7/8), 843-856.

Siegel, D.S. and P. Phan (2005), Analyzing the Effectiveness of University Technology Transfer: Implications for Entrepreneurship Education, in: Liebcap, G. (ed.) Advances in the Study of Entrepreneurship, Innovation, and Economic Growth, Amsterdam, 138.

Siegel, D.S., D. Waldman and A. Link (2003), Assessing the Impact of Organizational Practices on the Relative Productivity of University Technology Transfer Offices: An Exploratory Study, Research Policy 32, 27-48.

Thursby, J.G., A. Fuller and M.C. Thursby (2009), US Faculty Patenting: Inside and Outside the University, Research Policy 38, 14-25.

Thursby, J.G. and S. Kemp (2002), Growth and Productive Efficiency of University Intellectual Property Licensing, Research Policy 31, 109-124.

Thursby, J.G. and M.C. Thursby (2002), Who Is Selling the Ivory Tower? Sources of Growth in University Licensing, Management Science 48, 90-104.

Trajtenberg, M., R. Henderson and A. Jaffe (1997), University Versus Corporate Patents: A Window on the Basicness of Inventions, Economics of Innovation and New Technologies 5, 19-50. 


\section{Appendix}

\section{Table 4: Industry classification}

\begin{tabular}{|l|l|l|}
\hline Abbreviation & Industry & NACE2 code \\
\hline Industry 1 & Manufacture of food, tobacco and textiles, clothing & $15,16,17,18,19$ \\
\hline Industry 2 & $\begin{array}{l}\text { Manufacture wood, cork, straw and plaiting materials, publishing, } \\
\text { printing and reproduction of recorded media }\end{array}$ & $20,21,22$ \\
\hline Industry 3 & Manufacture chemicals and plastics & $23,24,25$ \\
\hline Industry 4 & Manufacture of other non-metallic mineral products & 26 \\
\hline Industry 5 & Manufacture of basic metals and fabricated metal products & 27,28 \\
\hline Industry 6 & Manufacture of machinery and equipment & 29 \\
\hline Industry 7 & Manufacture of office machinery, electrical machinery, communication & $30,31,32,33$ \\
\hline Industry 8 & Manufacture of transport equipment and manufacture n.e.c. & $34,35,36,37$ \\
\hline
\end{tabular}


Table 5: Variable Definitions

\begin{tabular}{|c|c|}
\hline Variable name & Description \\
\hline R\&D/employment 2002 & $\begin{array}{l}\text { R\&D expenditure in } 1000 \text { EUR divided by full-time employees in } \\
2002\end{array}$ \\
\hline R\&D/employment 2001 & $\begin{array}{l}\text { R\&D expenditure in } 1000 \text { EUR divided by full-time employees in } \\
2001\end{array}$ \\
\hline Innovation sales/total sales 2003 & $\begin{array}{l}\text { Sales with products new to the market in } 1000 \text { EUR in the period } \\
2001-2002\end{array}$ \\
\hline Innovation sales/total sales 2002 & $\begin{array}{l}\text { Sales with products new to the market in } 1000 \text { EUR in the period } \\
2000-2001\end{array}$ \\
\hline I(Innovation sales/employment $2003>0$ ) & $\begin{array}{l}\text { Dummy variable that takes the value } 1 \text { if innovation sales are } \\
\text { larger than zero in } 2003\end{array}$ \\
\hline I(Innovation sales/employment $2002>0$ ) & $\begin{array}{l}\text { Dummy variable that takes the value } 1 \text { if innovation sales are } \\
\text { larger than zero in } 2002\end{array}$ \\
\hline Share of skilled labor force 2002 & Share of employees with a university degree in 2002 \\
\hline No. of skilled workers 2002 & Number of employees with a university degree in 2002 \\
\hline Skilled labor force/R\&D 2002 & $\begin{array}{l}\text { Number of employees with a university degree over R\&D } \\
\text { expenses in } 2002\end{array}$ \\
\hline Share of skilled labor force 2001 & Share of employees with a university degree in 2001 \\
\hline No. of skilled workers 2001 & Number of employees with a university degree in 2001 \\
\hline Employment $_{2002}$ & Number of full time employees in 2002 \\
\hline Employment $_{2001}$ & Number of full time employees in 2001 \\
\hline Product innovator & $\begin{array}{l}\text { Dummy variable that indicates whether the firm introduced new } \\
\text { or significantly improved products or services in the period 2000- } \\
2002\end{array}$ \\
\hline Process innovator & $\begin{array}{l}\text { Dummy variable that indicates whether the firm introduced new } \\
\text { or significantly improved processes in the period 2000-2002 }\end{array}$ \\
\hline Scientists per 1000 inhabitants in region 2000 & $\begin{array}{l}\text { Number of scientists per } 1000 \text { inhabitants per NUTS3 region } \\
\text { (“Landkreis”) }\end{array}$ \\
\hline Export sales $_{2002}$ & Sales with exports in 1000 EUR in 2002 \\
\hline Export sales $_{2001}$ & Sales with exports in 1000 EUR in 2001 \\
\hline East Germany & Dummy variable indicating firm location in Eastern Germany \\
\hline Firm age & Age of the firm in years \\
\hline Part of a firm group & Dummy variable indicating whether a firm is part of a firm group \\
\hline ... with a headquarter outside of Germany & $\begin{array}{l}\text { Dummy variable indicating whether a firm is part of a firm group } \\
\text { with a headquarter located outside of Germany }\end{array}$ \\
\hline
\end{tabular}

